\title{
Transnasal Sphenopalatine Ganglion Block For Treatment of Post-Dural Puncture Headache in Obstetric Population
}

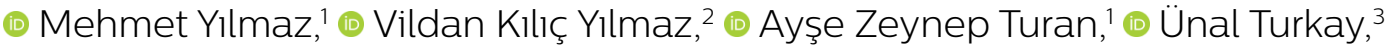 \\ ๑ Hasan Terzi, ${ }^{3}$ @ Yunus Gürkan Türker, ${ }^{4}$ @ Kemal Tolga Saraçoglu ${ }^{5}$
}

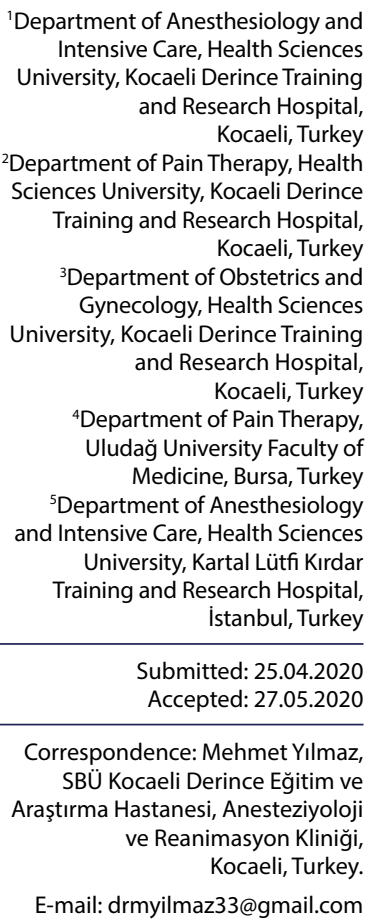
and Research Hospital Kocaeli, Turkey

2Department of Pain Therapy, Health Sciences University, Kocaeli Derince

Training and Research Hospital, Kocaeli, Turkey

${ }^{3}$ Department of Obstetrics and Gynecology, Health Sciences University, Kocaeli Derince Training and Research Hospital, Kocaeli, Turkey

${ }^{4}$ Department of Pain Therapy, Uludağ University Faculty of Medicine, Bursa, Turkey

${ }^{5}$ Department of Anesthesiology and Intensive Care, Health Sciences University, Kartal Lütfi Kırdar

Training and Research Hospital, İstanbul, Turkey

Submitted: 25.04 .2020 Accepted: 27.05.2020

Correspondence: Mehmet Yılmaz SBÜ Kocaeli Derince Eğitim ve Araştırma Hastanesi, Anesteziyoloji ve Reanimasyon Kliniği, Kocaeli, Turkey.

E-mail: drmyilmaz33@gmail.com

(a)

Keywords: Post-dural puncture headache; sphenopalatine ganglion block; spinal anesthesia.

\section{ABSTRACT}

Objective: Pain control for a post-dural puncture headache (PDPH) can be challenging. Epidural blood patching (EBP) is recommended; however, EBP is an interventional procedure with the risk of bleeding, infection, and adverse neurological effects. The aim of this study was to evaluate the effects of a transnasal sphenopalatine ganglion block (SPGB) as supportive PDPH treatment.

Methods: Pregnant women undergoing a cesarean section under spinal anesthesia who developed PDPH were included in this prospective randomized study. The enrolled subjects were randomly assigned to 2 groups: a medical treatment group $(n=10)$ and a group that would receive medical treatment with the addition of SPGB $(n=10)$. Visual analog scale (VAS) scores were recorded at the time of admission, and at 4, 12, and 24 hours after treatment.

Results: There was no statistically significant difference between the 2 groups in terms of age, height, weight, or body mass index. The mean VAS values at the baseline, $12^{\text {th }}$ hour, and $24^{\text {th }}$ hour were similar between the groups. However, the mean VAS score at the fourth hour was significantly lower in the block group $(p=0.002)$.

Conclusion: A unilateral SPGB is a rapid and effective method to treat PDPH. However, the safety of this technique requires further research due to complications encountered, including a seizure.

\section{INTRODUCTION}

Post-dural puncture headache (PDPH) can occur after the administration of spinal anesthesia due to leakage from the dural and arachnoid puncture. ${ }^{[1]}$ An excessive loss of cerebrospinal fluid (CSF) induces low pressure in the intrathecal space, which subsequently leads to increased tension on the falx cerebri, cerebral blood vessels, and tentorium cerebelli. ${ }^{[2]}$ Another mechanism for the development of PDPH is distension of blood vessels. Lower pressure in the cranium due to CSF leakage without a concurrent reduction of intravenous pressure can lead to dilatation of the cranial blood vessels. 
The gold standard treatment of PDPH is epidural blood patching (EBP). ${ }^{[3]}$ However, EBP is an interventional procedure that can produce several additional complications, such as bleeding, infection, and adverse neurological effects. Additionally, it can increase the risk of a recurrent dural puncture. ${ }^{[4]}$ Conservative treatment of PDPH consists of intravenous fluid replacement, analgesic agents, and theophylline. ${ }^{[5]}$

A transnasal sphenopalatine ganglion block (SPGB) has been successful in the treatment of migraines, status migrainosus, cluster-type headaches, and atypical facial pain. ${ }^{[6-8]}$ Over the last few years, the use of transnasal SPGB to treat PDPH has been reported in case series and case reports with a low risk of complications. ${ }^{[9-11]}$ SPGB is minimally invasive and easier to perform than EBP. ${ }^{[1,13]}$ SPGB can also be beneficial in cases with contraindications for EBP, such as coagulopathy, septicemia, or puncture site infection.

This clinical study evaluated the effects of SPGB as supportive PDPH treatment.

\section{MATERIALS AND METHODS}

This prospective study was initiated following receipt of approval from the local ethics committee (Kocaeli University Clinical Research Ethics Committee, KOU KAEK: 2017/360). The study was registered at www.clinicaltrials. gov prior to patient enrollment (clinical trial registration number: NCT035 I2977). Pregnant women who underwent a cesarean section with spinal anesthesia between December 2017 and June 2018 and developed PDPH after spinal anesthesia were enrolled in the study. Randomization was performed using the random number generator available at https://www.random.org. Patients with bilateral nasal septal deviations, epilepsy, lidocaine allergy, or epileptic seizures during treatment were excluded. In total, 21 pregnant women were enrolled. A sealed envelope was used to make random assignments to receive the standard treatment (control group) or the standard treatment and a transnasal SPGB (block group). Written, informed consent was obtained from each participant.

All of the enrolled subjects diagnosed with PDPH were admitted to hospital, and the International Classification of Headache Disorders criteria were used to confirm the diagnosis. ${ }^{[14]}$ PDPH was diagnosed based on a headache occurring within 5 days of the application of spinal anesthesia with frontal-occipital spread and aggravation while standing and relief in the supine position. Each patient's demographic data of age and body mass index (BMI), smoking and drinking habits, medication history, and comorbidities were obtained at the time of admission. The spinal needle size and type, onset of pain, start of treatment, and additional symptoms, such as nausea, vomiting, tinnitus, or visual impairment, were recorded.

All of the patients received a $1000 \mathrm{~mL} 0.9 \%$ normal saline infusion over the initial 4 hours and $1500 \mathrm{mg}$ of magnesium sulfate $\left(\mathrm{MgSO}_{4}\right), 200 \mathrm{mg}$ of intravenous theophylline, and $1000 \mathrm{mg}$ of paracetamol (acetaminophen). Intravenous flu- id replacement, $\mathrm{MgSO}_{4}$, and paracetamol therapy was continued over the next 24 hours. Paracetamol was prescribed at a dosage of $1000 \mathrm{mg} 4$ times daily. The participants in the block group underwent a unilateral SPGB, as defined by Cohen et al. ${ }^{[15]}$ in addition to the standard therapy. Each was instructed to assume a supine position with a mild cervical extension. A cotton-tipped applicator stick with 2 $\mathrm{mL}$ of $10 \%$ lidocaine was advanced gently into one side of the nasal cavity until the physician felt the resistance of the posterior nasal wall. The physician confirmed that the applicator stick was in the correct location, and the subject's tolerance was tested by rotating the applicator stick. The applicator was left in the nasal cavity for 15 minutes.

The participant's headache pain was recorded using a visual analogue scale (VAS) while the subject was in a standing position at the time of admission $\left(T_{1}\right)$ and after treatment at 4 hours $\left(T_{2)}, 12\right.$ hours $\left(T_{3}\right)$, and 24 hours $\left(T_{4}\right)$. Complications experienced during the intervention and treatment were recorded. The patients were discharged 24 hours after the treatment, and contact information was provided for use in the event of any adverse event or headache recurrence.

\section{Statistical analysis}

All of the statistical analyses were performed using IBM SPSS Statistics for Windows, Version 25.0 (IBM Corp., Armonk, NY, USA). In order to compare the numeric data, an independent samples t-test (2-sided) was used to determine normal distribution, and the Mann-Whitney $U$ test (2-sided) was used for non-normal distribution. Fisher's exact test was used for the analysis of discrete variables. The results were within a $95 \%$ confidence interval, and a $p$ value of $<0.05$ was considered significant. In our study of 20 patients, with a $95 \%$ confidence interval, the power was calculated to be $83 \%$, and the effect size was determined to be 1.39 .

\section{RESULTS}

A total of 21 women aged between 18 and 40 years were initially enrolled in this study. One participant who had an epileptic seizure after the SPGB was excluded; thus, the data from 20 subjects were analyzed. No other serious complication occurred. Additionally, blood was detected on the applicator after the SPGB application in I participant. There was no statistically significant difference between the 2 groups in terms of age, height, weight, or BMI $(p=0.550$, $p=0.402, p=0.052$, and $p=0.165$, respectively; Table I).

The mean VAS values at baseline, the $12^{\text {th }}$ hour, and the $24^{\text {th }}$ hour were similar between the 2 groups $(p=0.436$, $p=0.089$, and $p=0.089$, respectively; Table 2 ). However, the mean VAS value at the fourth hour was significantly lower in the block group ( $p=0.002$; Table 2$)$. The initial treatment began at $20 \pm 14.25$ hours in the medical treatment group, whereas in the medical treatment with the addition of SPBG group, it was performed at $17 \pm 22.5$ hours $(p=0.912)$. In addition, no significant differences were ob- 
Table I. Comparison of demographic characteristics

\begin{tabular}{lccr}
\hline & $\begin{array}{c}\text { Medical treatment group } \\
(\mathbf{n}=1 \mathbf{0})\end{array}$ & $\begin{array}{c}\text { Medical treatment }+ \text { SPGB group } \\
(\mathbf{n}=1 \mathbf{0})\end{array}$ & $\mathbf{p}$ \\
\hline Age $($ years $)$ & $26.9 \pm 5.2$ & $28.4 \pm 5.8$ & $0.550^{*}$ \\
Weight $(\mathrm{kg})$ & $76.3 \pm 12.98(71)$ & $70.10 \pm 19.52(63.5)$ & $0.052^{* *}$ \\
Height $(\mathrm{cm})$ & $160.6 \pm 3.98$ & $158.4 \pm 7.06$ & $0.402^{*}$ \\
Body mass index & $26.61 \pm 5.01(27.5)$ & $27.99 \pm 7.68(25.3)$ & $0.165^{* *}$ \\
\hline
\end{tabular}

"Independent samples t-test: Values are given as mean \pm SD; **Mann-Whitney $U$ test: Values are given as mean $\pm S D$ (median). SPGB: Sphenopalatine ganglion block.

Table 2. Comparison of visual analogue scale scores

\begin{tabular}{lccc}
\hline & $\begin{array}{c}\text { Medical treatment group } \\
(\mathbf{n}=10)\end{array}$ & $\begin{array}{c}\text { Medical treatment }+ \text { SPGB group } \\
(\mathbf{n}=1 \mathbf{0})\end{array}$ & $\mathbf{p}$ \\
\hline 0 hours & $7.6 \pm 1.96(7.5)$ & $8.3 \pm 1.95(8.5)$ & $0.436^{*}$ \\
$4^{\text {th }}$ hour & $4 \pm 0.67$ & $2.2 \pm 1.14$ & $0.002^{* *}$ \\
$12^{\text {th }}$ hour & $3.1 \pm 2.38(2.5)$ & $1.5 \pm 2.1(0.5)$ & $0.089^{*}$ \\
$24^{\text {th }}$ hour & $3.1 \pm 2.88(3)$ & $1.1 \pm 1.45(0.5)$ & $0.089^{*}$ \\
\hline
\end{tabular}

"Independent samples t-test: Values are given as mean \pm SD; "Mann-Whitney $U$ test: Values are given as mean $\pm S D$ (median). SPGB: Sphenopalatine ganglion block.

Table 3. Comparison of accompanying symptoms

\begin{tabular}{|c|c|c|c|c|c|}
\hline \multirow[b]{2}{*}{ Nausea } & \multicolumn{2}{|c|}{ Medical treatment group $(n=10)$} & \multicolumn{2}{|c|}{ Medical treatment + SPGB group $(n=10)$} & \multirow{2}{*}{$\begin{array}{c}\mathbf{P} \\
0.628^{*}\end{array}$} \\
\hline & + & 4 & + & 2 & \\
\hline & - & 6 & - & 8 & \\
\hline \multirow[t]{2}{*}{ Vomiting } & + & I & + & 1 & $1.000^{*}$ \\
\hline & - & 9 & - & 9 & \\
\hline \multirow[t]{2}{*}{ Tinnitus } & + & I & + & 3 & $0.582^{*}$ \\
\hline & - & 9 & - & 7 & \\
\hline \multirow[t]{2}{*}{ Visual impairment } & + & 0 & + & I & $1.000^{*}$ \\
\hline & - & 10 & - & 9 & \\
\hline \multirow[t]{2}{*}{ Stiff neck } & + & 2 & + & 5 & $0.350^{*}$ \\
\hline & - & 8 & - & 5 & \\
\hline
\end{tabular}

"Fisher's exact test: Values are given as frequency (percentage). SPGB: Sphenopalatine ganglion block.

Table 4. Correlation between initial treatment time and VAS values

\begin{tabular}{llccr}
\hline & & VAS at $4^{\text {th }}$ hour & VAS at I2 $^{\text {th }}$ hour & VAS at 24 ${ }^{\text {th }}$ hour \\
\hline Initial treatment time & Correlation & .296 & .255 & .065 \\
& Sig. (2-tailed) & .205 & .278 & .784 \\
\hline
\end{tabular}

Bivariate correlations test. VAS: Visual analogue scale score.

served in the accompanying symptoms (all $p$ values $>0.05$; Table 3). The initial treatment time and VAS values at $T_{1}$, $T_{2}, T_{3}$, and $T_{4}$ demonstrated no statistically significant relationships (Table 4).

\section{DISCUSSION}

This randomized comparative study evaluated the effects of transnasal SPGB on PDPH. The VAS values at the fourth hour were lower in the SPGB group. There were no significant differences between the groups in terms of complications or additional symptoms.

A PDPH is a severe clinical impairment that can lead to severe morbidity, affect maternal care and self-care, prolong hospital stay, and even become chronic. The EBP timing and method remain controversial, and the intervention success rate is $<70 \%$, according to the literature. ${ }^{[4]}$ SPGB is a safe treatment method that has been described in sev- 
eral recent case reports. In the current study, the participants reported a mean VAS score of 8.5 at the time of admission and 2.2 at the fourth hour in the SPGB group, which indicated a $75 \%$ improvement in symptoms. As mentioned, no previous study has compared SGGB and EBP efficacy. ${ }^{[16]}$ The results of our study indicate that since EBP includes many additional risks, SPGB may be a safer means of improving patient comfort and become the first choice of treatment approach in PDPH patients. In addition, in the SPGB group, there was no increase in VAS score during the day, and the clinical course was stable. The only significant difference found in our study was at the fourth hour. Although there was no statistically significant difference between the groups in the VAS values at the $12^{\text {th }}$ and $24^{\text {th }}$ hours, there was a decrease in VAS values in the SPGB group, and the $p$ value was close to the significance limit at $\mathbf{0 . 0 8 9}$. We concluded that this difference might be related to the sample size. In another study of 20 parturients, $88.89 \%$ of patients in the SPGB group had adequate pain relief within 5 minutes. ${ }^{[17]}$ The pain was reduced for as much as 8 hours without any adverse effect. In our study, even after 24 hours, the VAS scores were lower in the treatment group.

SPGB is a simple, effective, and repeatable block method that is a minimally invasive treatment method for a mild PDPH. ${ }^{[18,19]}$ Dubey et al. ${ }^{[20]}$ treated II patients with PDPH and reported that 6 patients had complete relief after SPGB. Five patients required another block after I hour. The fourth-hour VAS scores were lower in our patients who underwent only a single, unilateral treatment, which suggests high effectiveness. A concentration of $4-5 \%$ lidocaine or a long-acting agent, such as bupivacaine or tetracaine, could be administered in resistant subjects. Ropivacaine is another potential choice of local anesthetic agent. Furtado et al. ${ }^{[10]}$ administered ropivacaine at a concentration of $0.75 \%$ into each nostril and found that among 4 patients, pain was controlled in 3 with a single intervention, while I patient required repeated intervention.

Two complications arose during our study. One participant had a generalized tonic-clonic seizure 2 hours after the SPGB. The duration of the seizure was less than a minute, and magnetic resonance imaging after the seizure revealed cerebral edema. Our treatment protocol consisted of only a single 200-mg dose of theophylline, which should not have caused the seizure. A blood-stained applicator was noted after performing the block in another participant. In the clinical follow-up, there were no complaints or active bleeding. Minor complications and discomfort during the SPGB were evaluated as more tolerable when compared with EBP. A recent retrospective study evaluated 39 subjects who underwent EBP and 42 subjects who underwent SPGB. Approximately $40 \%$ of the SPGB group recovered from headache within 30 minutes and $71.4 \%$ within I hour (vs. $20.5 \%$ and $30.8 \%$, respectively in the EBP group). ${ }^{[2]}$ However, potential complications remain a concern, and further research is needed. Recently, the use of SPGB in combination with greater and lesser occipital nerve blocks has been suggested for the management of PDPH. ${ }^{[22]}$

The small sample size of our study is the primary limitation; however, the VAS scores at the fourth hour were significantly different. Clinical trials with a larger sample size are needed to support our results. The VAS scoring was not blinded; neither the participants nor the physicians were blind to the assessment. In addition, there was no control group with a cotton-tip applicator placement without lidocaine, as we aimed to compare only the medication and intervention groups.

In conclusion, unilateral SPGB is a rapid and effective method for the treatment of PDPH. Although further clinical trials are required and questions remain about the safety of this technique, SPGB may provide a first treatment step for PDPH cases.

Ethics Committee Approval

Approved by the local ethics committee (Kocaeli University Clinical Research Ethics Committee, KOU KAEK: 2017/360).

\section{Informed Consent}

Prospective study.

Peer-review

\section{Internally peer-reviewed.}

Authorship Contributions

Concept: M.Y.; Design: V.K.Y., Y.G.T.; Supervision: K.T.S.; Fundings: A.Z.T.; Materials: M.Y.; Data: Ü.T., H.T.; Analysis: M.Y.; Literature search: V.K.Y., Ü.T., H.T.; Writing: M.Y., A.Z.T.; Critical revision: Y.G.T., K.T.S.

\section{Conflict of Interest}

None declared.

\section{REFERENCES}

1. Jabbari A, Alijanpour E, Mir M, Bani Hashem N, Rabiea SM, Rupani MA. Post spinal puncture headache, an old problem and new concepts: review of articles about predisposing factors. Caspian J Intern Med 2013;4:595-602.

2. Gaiser RR. Postdural puncture headache: a headache for the patient and a headache for the anesthesiologist. Curr Opin Anaesthesiol 2013;26:296-303.

3. Ioscovich A, Giladi Y, Fuica RL, Weiniger CF, Orbach-Zinger S, Gozal Y, et al. Anesthetic approach to postdural puncture headache in the peripartum period: An Israeli national survey. Acta Anaesthesiol Scand 2018;62:1460-5.

4. Bradbury CL, Singh SI, Badder SR, Wakely LJ, Jones PM. Prevention of post-dural puncture headache in parturients: a systematic review and meta-analysis. Acta Anaesthesiol Scand 2013;57:417-30.

5. Wu C, Lian Y, Guan D, Wang L, Miao Y, Xie N, et al. A Multicenter Clinical Study on Treating Post-Dural Puncture Headache with an Intravenous Injection of Aminophylline. Pain Physician 2016;19:E761-E5.

6. Láinez MJ, Puche M, Garcia A, Gascón F. Sphenopalatine ganglion stimulation for the treatment of cluster headache. Ther Adv Neurol Disord 2014;7:162-8.

7. Narouze S. Neurostimulation at pterygopalatine fossa for cluster 
headaches and cerebrovascular disorders. Curr Pain Headache Rep 2014;18:432.

8. Mehta D, Leary MC, Yacoub HA, El-Hunjul M, Kincaid H, Koss V, et al. The Effect of Regional Anesthetic Sphenopalatine Ganglion Block on Self-Reported Pain in Patients With Status Migrainosus. Headache 2019;59:69-76.

9. Kent S, Mehaffey G. Transnasal sphenopalatine ganglion block for the treatment of postdural puncture headache in obstetric patients. J Clin Anesth 2016;34:194-6.

10. Furtado I, Lima IF, Pedro S. Ropivacaine use in transnasal sphenopalatine ganglion block for post dural puncture headache in obstetric patients - case series. Rev Bras Anestesiol 2018;68:421-4.

11. Channabasappa SM, Manjunath S, Bommalingappa B, Ramachandra S, Banuprakash S. Transnasal sphenopalatine ganglion block for the treatment of postdural puncture headache following spinal anesthesia. Saudi J Anaesth 2017;11:362-3.

12. Gonçalves LM, Godinho PM, Durán FJ, Valente EC. Sphenopalatine ganglion block by transnasal approach in post-dural puncture headache. J Clin Anesth 2018;48:50.

13. Kent $\mathrm{S}$, Mehaffey $\mathrm{G}$. Transnasal sphenopalatine ganglion block for the treatment of postdural puncture headache in the ED. Am J Emerg Med 2015;33:1714.e1-1714.e2.

14. Kwak KH. Postdural puncture headache. Korean J Anesthesiol 2017;70:136-43.

15. Cohen S, Ramos D, Grubb W, Mellender S, Mohiuddin A, Chiricolo A. Sphenopalatine ganglion block: a safer alternative to epidural blood patch for postdural puncture headache. Reg Anesth Pain Med 2014;39:563.

16. Araújo R, Pinho S, Xavier J, Cabido H, Cavaleiro C, Machado H. Sphenopalatine ganglion block followed by an epidural blood patch for postdural puncture headache management in postpartum patients: is it a confounder? Reg Anesth Pain Med. 2019 Jan 11. doi: 10.1136/rapm-2018-100046. [Epub ahead of print].

17. Puthenveettil N, Rajan S, Mohan A, Paul J, Kumar L. Sphenopalatine ganglion block for treatment of post-dural puncture headache in obstetric patients: An observational study. Indian J Anaesth 2018;62:972-7.

18. Cohen S, Sakr A, Katyal S, Chopra D. Sphenopalatine ganglion block for postdural puncture headache. Anaesthesia 2009;64:574-5.

19. Nair AS. Bilateral transnasal sphenopalatine block for treating postdural puncture headache. Korean J Anesthesiol 2018;71:73-4.

20. Dubey P, Dubey PK. Intranasal lignocaine spray for sphenopalatine ganglion block for postdural puncture headache. Saudi J Anaesth 2018;12:364-5.

21. Cohen S, Levin D, Mellender S, Zhao R, Patel P, Grubb W, et al. Topical Sphenopalatine Ganglion Block Compared With Epidural Blood Patch for Postdural Puncture Headache Management in Postpartum Patients: A Retrospective Review. Reg Anesth Pain Med 2018;43:880-4.

22. Urits I, Viswanath O, Orhurhu V, Petro J, Cai V. Sphenopalatine ganglion block in combination with greater and lesser occipital nerve blocks for the management of post dural puncture headache. J Clin Anesth 2019;52:69-70.

\section{Obstetrik Popülasyonda Post-Dural Ponksiyon Baş Ağrısının Tedavisi İçin Transnasal Sfenopalatin Ganglion Bloğu}

Amaç: Post-dural ponksiyon baş ağrısı (PDPH) ağrı kontrolü zorlayıcı olabilir. PDPH tedavisinde epidural kan yaması (EBP) önerilir. EBP kanama, enfeksiyon ve norolojik istenmeyen etkileri olan girişimsel bir prosedürdür. Bu çalsşmada destekleyici PDPH tedavisine eklenen transnazal sfenopalatin gangliyon bloğunun (SPGB) etkisini değerlendirmeyi amaçladık.

Gereç ve Yöntem: Spinal anestezi altında sezaryen operasyonu geçiren ve PDPH gelişen gebe kadınlar ileriye yönelik randomize olarak çaıışmaya dahil edildi. Hastalar rastgele, destekleyici tedavi alan $(n=10)$ ve destekleyici tedaviye SPGB eklenenler $(n=10)$ olarak iki gruba ayrıldı. Hastaların PDPH şiddeti Visual analog scale (VAS) ile değerlendirildi. VAS değerleri başvuru sırasında $\left(T_{1}\right)$, tedaviden sonraki dördüncü ( $\left.T_{2}\right)$, on ikinci $\left(T_{3}\right)$ ve yirmi dördüncü saatte $\left(T_{4}\right)$ kayıt altına alındı.

Bulgular: íki grup arasında yaş, boy, kilo ve vücut kitle indeksi açııından istatistiksel olarak anlamlı fark yoktu. Ayrıca başvuru sırasındaki, 12. ve 24. saatteki VAS değerleri iki grup arasında benzer bulundu. Ancak destek tedavisine SPGB eklenen grupta dördüncü saatteki VAS değeri anlamlı olarak düşük bulundu $(\mathrm{p}=0.002)$.

Sonuç: Sonuç olarak tek taraflı SPGB, PDPH akut tedavisinde hızlı, etkili ve güvenli bir yöntem olarak kullanılmıştır. Illeri çalışmalara gereksinim olmakla beraber PDPH tedavisinde ilk tedavi seçeneği olarak kullanılabileceği kanısına varılmıştır.

Anahtar Sözcükler: Post-dural ponksiyon baş ağrısı; sfenopalatin ganglion blok; spinal anestezi. 